\title{
Parental and Peer Influence on the Saving Behavior of the Youth
} Jeetendra Dangol, $\mathrm{PhD}^{\star}$ and Saru Maharjan ${ }^{\star \star}$

\begin{abstract}
This paper explores the parental and peer factors which influence the saving behavior of the youth. This paper is based on a structured questionnaire with various dimensions of the saving behavior, parental and peer influence. Judgmental and convenience sampling techniques were used to collect the data of 390 respondents from Kathmandu Valley who have completed Master's degree and are employed. The study reveals that there is significant relationship between peer influence and saving behavior. Similarly, there is significant relationship between parental financial teaching and saving behavior. Independence, control, habit formation, encouraging saving are mechanisms that influences saving behavior. However parent's encouragement to save highly affects the saving behavior. Therefore receiving financial teaching from parents ensures sound saving behavior.
\end{abstract}

Key Words: Saving Behavior, Parental and Peer Influence

\footnotetext{
*Associate Professor, Tribhuvan University, Email: jdangol@gmail.com and ${ }^{*}$ Freelance Researcher
} 


\section{Introduction}

Horne and Wachowicz (2008) proposed financial management behavior as the determination, acquisition, allocation and utilization of financial resources with overall goal in mind while Grable, Park and Joo (2009) explained personal financial management as the set of behaviors performed regarding the planning, implementing, and evaluating involved in the areas of cash, credit, investments, insurance and retirement and estate planning. It involves all the financial decisions and activities of an individual or household - the practices of earning, saving, investing and spending.

Financial management and decision of people differ from one another. Many individuals and families have little knowledge or skill to handle the financial decisions like purchasing the assets, short term saving, retirement savings, borrowing and consumption. In household sector, youth is an important group of people who are the future leaders, and could contribute much in the development process. This could affect the country's inclusive growth in the long run, understanding the saving behavior of the different social groups whose actions could bring about changes in the economy is crucial for the development (Furnham, 1985). Therefore, understanding the financial behavior of the youth leads to growth and development of the country.

Katona (1974) defined saving as part of income which is reserved for future use and may therefore serve to create enduring wealth. For the individual, the absence of financial worries, which could be helped through saving, is associated with subjective well-being As per Dowling, Corney and Hoiles, (2009), right decision leads in personal development and growth as well as to promote positive saving behaviors and to predict financial problems. Hence saving behavior determines the social well-being and provides the solution to the financial problems in the future.

Adolescents have larger budgets and are more willing to spend. They make many independent choices. Peer groups, parents, teachers and other adults are more influential factors for making such choices. They engage in many economic activities to be independent (Youniss \& Haynie, 1992). Family financial difficulties reduces the productivity in work place, affect the health physically, economically and psychologically. They basically get support from their family members like monthly allowance to support their life. However, University students take higher responsibility of personal financial management. They face many challenges like credit card use, paying monthly expenses, working, saving and debt management. Hence it is necessary for young individuals to have basic knowledge and skills to make personal financial decisions (Peng, Bartholomae, Fox \& Cravener, 2007). Youth have to go through different financial decisions as they have to pay for colleges, take credit to pay such expenses. Without having proper guidance and modelling it is difficult to take right decisions. 
Youniss and Haynie (1992) opined that both peer and parent remain as strong socialization agent that determine the behavior of adolescence in future. Their needs were often derived from desires than the financial needs. From childhood they imitated what their parents do. People who discuss financial problems with parents had better skills to fulfill the financial needs. Young people also learnt from direct and indirect interaction with peers; through discussions, rulemaking, reinforcement and modeling. Salikin, Wahab, Zakaria, Masruki and Nordin (2012) found that parental educational background and household income affects the saving tendency of students. Mother's level of education affected the tendency to save for students.

Bucciol and Veronesi (2014) suggested that parental teaching is more effective than receiving the formal education at school and based on different socio demographic variables they show different behavior. Parental teaching method determines the ability to meet financial issues in future and it is more effective especially when different teaching methods are combined. The most effective strategy is teaching to save during childhood and adolescence. Delafrooz and Paim (2011) showed income, age, financial management and financial literacy as the most influential predictors of saving behavior. Regarding to gender, Xiao and Noring (1994) stated that male heads were more likely to report saving for retirement, children and growth while female heads were more likely to report saving for daily expense. Grinstein-Weiss, Zhan and Sherraden (2006) showed that married people tend to save more than unmarried people.

This study aims to explore the parental and peer factors which influence the saving behavior of the youth.

In regard to the organization of subsequent parts of the paper, Section II presents a brief review of previous studies. This part also includes development of hypothesis. Similarly, Section III outlines the methodology employed in this study. Section IV presents the results and discussion, and finally, Section $\mathrm{V}$ contains conclusions of the paper.

\section{Literature Review Saving Behavior}

Browning and Lusardi (1996) implied that saving took place when money was left over and explained savings as excess of income over consumption over certain period of time. Saving behavior implied the perception of future needs, a saving decision and a saving action. Warneryd (1999) referred saving in psychological context as the process of not spending money for current period in order to be used in future. In other words, saving behavior is the combination of perceptions of future needs, a saving decision and a saving action. On the other hand, people are likely to define saving as investing, putting money 

in a bank account, speculating and paying off mortgages.

According to Katona (1975), someone's willingness to save/ consume would depend on financial expectations and attitudes. Those who want to save should have some willpower for making that decision and they still need to choose to do so. Willingness is determined by the economic environment and people's perceptions of it. Consumer expectations and consumer sentiment influence saving decisions. People save for many different reasons but economic condition influences contractual as well as discretionary saving decisions. Income, perceived need for money, bank accounts, self-control and future orientation are the factors that drive ability to save in childhood and adolescence (Webley \& Nyhus, 2006). Receiving money irregularly for certain activities more frequently, having bank accounts, having certain goals in future increases the propensity to save. As receiving money in childhood is the first chance to spend or save real money. Perceived need for money for activities to engage in with the friends, pay off the living expenses in adolescence impacts on consumption and saving patterns.

According to Shim, Barber, Card, Xiao, and Serido, (2009); Otto, Schots, Westerman and Webley, (2006), motives, self-efficacy, saving attitudes were important factors affecting the willingness to save in childhood and adolescence. An individual has simple goals in his/her mind for saving. Confidence will be important for the formation of saving goals. Lifestyle while growing up affects consumption pattern. It is necessary to know the reasons for saving and saving strategies. Keynes (1936) identified eight saving motives, and Browning and Lusardi (1996) added another, providing a title for each motive: (a) precautionary motive, (b) life-cycle motive, (c) inter temporal substitution motive, (d) improvement motive, (e) independence motive, (f) enterprise motive, (g) bequest motive, (h) avarice motive, and (i) down payment motive. Katona (1975) offered six more general saving motives: (a) for emergencies, (b) to have funds in reserve for necessities, (c) for retirement or old age, (d) for children's needs, (e) to buy a house or durable goods, and (f) for holidays.

Otto (2013) explained that children's and adolescents' ability and willingness to save did not only develop as a result of social learning (i.e. observation of role models) and direct teaching (such as explanations and guidance with regard to the spending and saving of pocket money or allowances). Skills and attitudes related to saving were indirectly related to parenting behaviors which led to higher self-efficacy beliefs, better self-regulation strategies, and more independent economic behavior. 


\section{Empirical evidences}

Bucciol and Veronesi (2014) revealed that parental teaching is more effective especially when different teaching methods are combined. The effective strategy is to teach saving during childhood and adolescence. Providing control over personal expenses, guiding and discussing about financial matters in family and giving advices increases the propensity to save for children in future.

Webley and Nyhus (2013) conducted two studies; Dutch study and Norwegian study to understand the economic socialization of the European young adults. Parental teaching about budgets and encouragement affected the future orientation of young adults. Individuals having encouragement preferred to save than spend, had better orientation for future, more conscientious and saved more. Norwegian evidence showed that parental affluence or education didn't impact the economic socialization practices. Parental practices had no association with income and education. Children had piggy banks and had access to saving accounts in bank. They were more likely to have bank accounts and received pocket money.

Karunaanithy, Karunanithy and Santhirasekaram (2017) explored the determinants of youth saving behavior in war torn areas of the Northern and Eastern part of Sri Lanka. The psychological factors that influence the saving behavior were parental socialization, peer influence and financial literacy and self-control. Parental socialization, peer influence and financial literacy contributed for the variance in the saving behavior by $31.5 \%, 10 \%$ and $6.5 \%$ respectively.

Jamal, Mohidin, Osman, Ramlan and Karim (2015) explored the savings behavior amongst students of higher learning institutions in Kota Kinabalu, Sabah. The study indicates that family involvement plays a major role in nurturing students' savings behavior, followed by financial literacy and peer influence. Involvement of students in spending activities, leisure time, discussing financial management issues with friends affected the saving behavior. Likewise strong family binding and influence of parents positively had impact on the future orientation of child.

Lusardi, Mitchell and Curto (2010) examined the long-term effects of high school peer influences on subsequent financial literacy and found that those with a high percentage of peers who planned to attend college have better knowledge on the inflation and risk diversification.

Friedline, Elliott, \& Nam (2011) examined the predicting factors of savings from adolescence to young adulthood using propensity score approach. The study examined 
the factors for predicting amount of savings which are having savings account during adolescence and having parents who own assets. Adolescents had more savings accounts and live in households where head of household was married, had more education and owned assets.

Salikin et al. (2012) revealed that parents' education background affects respective percentage and purposes of savings. If parents have higher level of educational background then students separate lower amount for savings.

Bashir, Hassan, Nasir, Baber and Shahid (2013) examined the determinants of saving behavior among male and female in the households of four important cities of Pakistan. The study showed that males and females had significantly different saving behaviors. Household expenses and income have positive impact for males and negative impact for females on saving behavior. The result showed that both male and female were different in all determinants of saving excluding education, work status, own home and risk tolerance levels as the determinants of saving. The study concluded that men saved more than females and women spend more than males.

Delafrooz and Paim (2011) examined the effects of demographic characteristics (gender, marital status, ethnic, age, level of education, income) on saving behavior and to determine factors (demographic variables, financial management practice and financial literacy) affecting the saving behavior among Malaysian employees. Results of the study indicated significant differences of saving behavior according to age, level of education and income. Furthermore, income, age, financial management and financial literacy were found to be the most influential predictors of saving behavior.

Conceptual Framework

\section{Independent Variables}

- Parental Educational Background

- Parental Financial Teaching

- Peer Influence

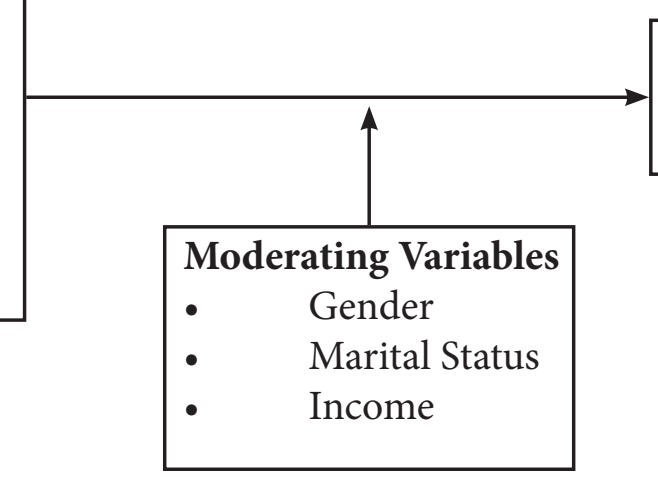

Dependent Variable Saving Behavior

Figure 2.1 Conceptual Framework 
Independent variables:

\section{Parental Educational Background}

Parents are the first teacher of child; the education that children receive at the first time is more dependent on the education that his or her parents received when they are children (Gratz, 2006). The higher education the parents have, the more likely they can teach the children toward the pressures and stresses of life, because the parents have at least the experience of being in the same position.

\section{Parental Financial Teaching}

Webley and Nyhus (2006) discovered that the approach of children to economic matters is linked to that of their parents. Different parental financial teaching includes parental modelling, discussion and guidance, habit formation and providing independence.

\section{Peer Influence}

Younis and Haynie (1992) mentioned that the influence of peers, parents remain strong socializing agents throughout young adult phase. They become less dependent on their parents and more oriented towards their peers as well as to the adult world as they compare their status with peer, discuss money management issues, spend their leisure time and involve in spending activities.

\section{Moderating Variables}

\section{Gender}

Falahati and Paim (2012) found that males and females perceived different levels of financial knowledge, financial skills and consumer experiences. Male students perceived earlier childhood consumer experiences and perceived a higher level of financial knowledge and financial skills than female students.

\section{Marital status}

Couples and single perceive the need of economic socialization in different way. Households with singles has a negative relationship with bank saving. When the husband expresses a preference for saving there is higher bank saving in those households and where wives have a longer planning horizon (Webley \& Nyhus, 2006). It means that couples and single show different financial behavior.

\section{Income}

Socio-economic status directly predicts financial satisfaction, and financial knowledge directly predicts healthy financial behaviors. It includes income, occupation and employment status. Shim et al. (2009) revealed that if parents have a higher SES status 
then they are more likely to provide financial resources to these students than those in a lower SES status.

\section{Dependent Variable}

\section{Saving Behavior}

Saving Behavior is the combination of perceptions of future needs, a saving decision and a saving action. Saving is important over the lifespan for retirement, to sustain stable consumption needs, to purchase a home or expensive goods, and to protect against unforeseen events such as unemployment spells or health problems.

\section{Hypothesis of the study}

H1: There is a significant relationship between peer influence and the saving behavior of the Nepalese youth.

H2: There is a significant relationship between parental educational background and saving behavior of the Nepalese youth.

H3: There is significant relationship between parental financial teaching and the saving behavior of the Nepalese youth.

H4: There is significant moderating role of gender, marital status and income of the Nepalese youth on their saving behavior.

\section{Research Method}

\section{Population and sample}

The population for this study constitutes individuals from age 21-40 who have completed their Master's Degree and working inside the Kathmandu Valley. The population for this study is unknown since there is no record of individuals who have completed Master's Degree and working. So, the sample size for the study included 392 individuals from different workplace. The study used judgmental and convenience sampling techniques to determine the sample. A structured questionnaire was distributed among the income generating individuals by visiting various organizations.

\section{Nature and Sources of data}

The information was collected by using primary method of data collection. Structured questionnaire was distributed for collecting the required information which include saving behavior, parental and peer influence. The study mainly uses Likert scale measurement for all the variables constructed in the proposed theoretical framework. In measuring the extent of peer influence four questions and for saving behavior five questions related to willingness to save, eight questions related to ability to save and one question related to total savings were adopted from Otto (2009). In measuring the extent of parental financial teaching four questions were adopted from Bucciol and Veronesi (2014). For parental 
educational background, the respondents were asked educational level of both father and mother and highest level of education level was chosen for study. The single choice questions, multiple choice questions and Likert scale questions were used to assess the data. The questionnaire has been divided into two sections whereby section 'A' consists of demographic profiles of the respondents while the three independent variables and dependent variable are asked in section 'B'.

\section{Data analysis}

The data obtained through the survey has been analyzed and interpreted using Statistical Package for Social Sciences Version 23 (SPSS 23) and Microsoft Excel.

\section{Linear Regression Model}

The linear regression model takes on the following form:

$\mathrm{Y}=\beta 0+\beta 1(\mathrm{PI})+\beta 2(\mathrm{PF})+\beta 3(\mathrm{PE})+\beta 4$ (moderating variables $)+$ ei...

Where,

$\mathrm{Y}=$ Saving Behavior

$\beta 0=$ Constant

$\mathrm{PI}=$ Peer Influence

$\mathrm{PF}=$ Parental Financial Teaching

$\mathrm{PE}=$ Parental Educational Background

Moderating variables $=$ income, gender, marital status

ei= Error Term

For analysis of saving behavior, peer influence and parental financial teaching Likert scale was used to determine the level of satisfaction ranging from 1 low to 5 high satisfaction level. Gender is coded as male and female, marital status is coded as married and unmarried, parental educational level is coded as below SLC, up to SLC, up to +2 , up to bachelors and up to master's level. Income is coded as below 20000, up to 30000, up to 40000, up to 50000 and above 50000. The coding of variables is shown in the table 3.2 below.

Table 1

\section{Coding of Variables}

Variables

Dependent Variable

Saving Behavior
Coding

Satisfaction level ranging from 1-5 ( 1 for lowest and 5 for highest) 
Independent Variables

Peer Influence

Satisfaction level ranging from 1-5 ( 1 for lowest and 5 for highest)

Parental Financial Teaching

Satisfaction level ranging from 1-5 ( 1 for lowest and 5 for highest)

Parental Educational Background

Below SLC level

1 if yes, 0 otherwise

Up to SLC level

1 if yes, 0 otherwise

Up to +2 level

1 if yes, 0 otherwise

Up to bachelors level

1 if yes, 0 otherwise

Masters and above

1 if yes, 0 otherwise

Moderating variables

Gender

Male (reference)

1

Female

0

Marital Status

Married

0

Unmarried (reference)

1

Monthly Income

Below 20000

1 if yes, 0 otherwise

20001-30000

1 if yes, 0 otherwise

30001-40000 (reference)

40001-50000

1 if yes, 0 otherwise

Above 50000

1 if yes, 0 otherwise

\section{Results}

\section{Purpose of Saving}

The respondents were asked about their reasons of saving with a multiple response question. The options provided in the questionnaire were savings to meet daily needs, savings for emergencies, saving for holiday, peer and parent.

Table 2 shows the purpose of saving of the youths. Around three fourth of respondents save for emergencies; half of the respondents save for fulfilling daily needs and vacation. The majority of the respondents (65.4 percent) saved due to peers, 35.1 percent of respondents 
saved because their parents tell them to, 3.1 percent save for other reasons. The other reasons are future contingencies, medical treatment and marriage.

Table 2

Reasons for saving

\begin{tabular}{lll}
\hline Reasons & $\mathrm{N}$ & Percent \\
\hline Parents tell me to & 137 & 35.1 \\
Peer save & 255 & 65.4 \\
Daily needs & 195 & 50.0 \\
Holiday & 198 & 50.8 \\
Emergency & 291 & 74.6 \\
Other & 12 & 3.1 \\
\hline
\end{tabular}

\section{Saving Behavior}

Saving behavior is the combination of perceptions of future needs, a saving decision and a saving action. Saving is important over the lifespan for retirement, to sustain stable consumption needs, and to protect against unforeseen events such as unemployment spells or health problems.

\section{Table 3}

Saving behavior

\begin{tabular}{llll}
\hline Variables & Number of Statements & Mean & Rank \\
\hline Ability to save & 8 & 3.60 & 1 \\
Willingness to save & 5 & 3.38 & 2 \\
Total savings & 1 & 1.99 & 3 \\
\hline
\end{tabular}

Table 3 shows the magnitude of saving behavior. The average mean score for willingness to save is 3.38. The average mean score for total savings is 1.99 and for ability to save is 3.60. The average mean score is highest for ability to save. It means the future contingencies, goals and orientation highly affects saving behavior of youth.

Relationship between Parental and Peer influence on Saving Behavior 
Pearson's correlation coefficient is calculated to show the relationship between saving behavior, parental educational level, parental financial teaching and peer influence. Table 4.10 illustrates the relationship between parental educational background, parental financial teaching, peer influence and saving behavior.

The correlation coefficient of peer influence and saving behavior is 0.321 ( $\mathrm{p}$-value $<0.05$ ) shows statistically positive correlation between peer influence and saving behavior of Nepalese youth. Similarly, the correlation coefficient of parental educational background and saving behavior is 0.019 shows that parental educational background and saving behavior have positive correlation. The $\mathrm{p}$-value of the correlation coefficient is equal to 0.705 . Hence, there is no statistically significant relationship between parental educational background and saving behavior of the Nepalese Youth.

The correlation coefficient of parental financial teaching and saving behavior is 0.187 ( $p$ value $<0.05$ ) shows that parental financial teaching and saving behavior have statistically positive relationship.

Table 4

Correlation matrix of parental and peer influence on saving behavior

\begin{tabular}{|c|c|c|c|c|c|}
\hline Variables & & $\begin{array}{l}\text { Saving } \\
\text { Behavior }\end{array}$ & $\begin{array}{l}\text { Parental } \\
\text { financial } \\
\text { Teaching }\end{array}$ & $\begin{array}{l}\text { Peer } \\
\text { Influence }\end{array}$ & $\begin{array}{l}\text { Parental } \\
\text { Educational } \\
\text { Background }\end{array}$ \\
\hline \multirow{3}{*}{$\begin{array}{l}\text { Saving } \\
\text { Behavior }\end{array}$} & Pearson & 1 & & & \\
\hline & Correlation & & & & \\
\hline & Sig. (2-tailed) & & & & \\
\hline \multirow{3}{*}{$\begin{array}{l}\text { Parental } \\
\text { Financial } \\
\text { Teaching }\end{array}$} & Pearson & $.187^{* *}$ & 1 & & \\
\hline & Correlation & & & & \\
\hline & Sig. (2-tailed) & .000 & & & \\
\hline \multirow[t]{2}{*}{ Peer Influence } & $\begin{array}{l}\text { Pearson } \\
\text { Correlation }\end{array}$ & $.321^{* *}$ & -.017 & 1 & \\
\hline & Sig. (2-tailed) & .000 & .737 & & \\
\hline
\end{tabular}


Parental

Pearson

.019

.023

.072

Educational Correlation

Background

Sig. (2-tailed) $\quad .705 \quad .648 \quad .154$

**. Correlation is significant at the 0.01 level (2-tailed).

\section{Multiple Regression Analysis}

The regression analysis consists of 5 different equations as it has three independent variables and three moderating variables. Table 5 shows the linear regression results of saving behavior as a dependent variable.

\section{Table 5}

Linear regression results of saving behavior as dependent variable

\begin{tabular}{|c|c|c|c|c|c|}
\hline Variables & Model-1 & Model-2 & Model-3 & Model-4 & Model-5 \\
\hline \multirow[t]{2}{*}{ Constant } & 2.28 & 2.27 & 2.26 & 2.33 & 2.32 \\
\hline & $(0.00)$ & $(0.00)$ & $(0.00)$ & $(0.00)$ & $(0.00)$ \\
\hline \multirow[t]{2}{*}{ Peer Influence } & 0.33 & 0.33 & 0.32 & 0.32 & 0.32 \\
\hline & $(0.00)$ & $(0.00)$ & $(0.00)$ & $(0.00)$ & $(0.00)$ \\
\hline \multirow{2}{*}{$\begin{array}{l}\text { Parental Financial } \\
\text { Teaching }\end{array}$} & 0.19 & 0.19 & 0.19 & 0.19 & 0.19 \\
\hline & $(0.00)$ & $(0.00)$ & $(0.00)$ & $(0.00)$ & $(0.00)$ \\
\hline \multirow[t]{2}{*}{ Below SLC } & 0.02 & 0.04 & 0.02 & 0.04 & 0.04 \\
\hline & $(0.72)$ & $(0.51)$ & $(0.73)$ & $(0.53)$ & $(0.51)$ \\
\hline \multirow[t]{2}{*}{ SLC } & -0.02 & 0.02 & -0.02 & 0.02 & 0.02 \\
\hline & $(0.74)$ & $(0.75)$ & $(0.71)$ & $(0.72)$ & $(0.73)$ \\
\hline \multirow[t]{2}{*}{ Bachelors } & 0.00 & 0.01 & 0.00 & 0.01 & 0.02 \\
\hline & $(0.93)$ & $(0.84)$ & $(0.73)$ & $(0.8)$ & $(0.78)$ \\
\hline \multirow[t]{2}{*}{ Masters } & 0.01 & 0.02 & 0.02 & 0.03 & 0.03 \\
\hline & $(0.80)$ & $(0.67)$ & $(0.75)$ & $(0.59)$ & $(0.61)$ \\
\hline Gender & & -0.03 & & & -0.03 \\
\hline (Male as reference) & & $(0.58)$ & & & $(0.57)$ \\
\hline
\end{tabular}


Jeetendra Dangol and Saru Maharjan: Parental and Peer Influence on the Saving Behavior of the Youth

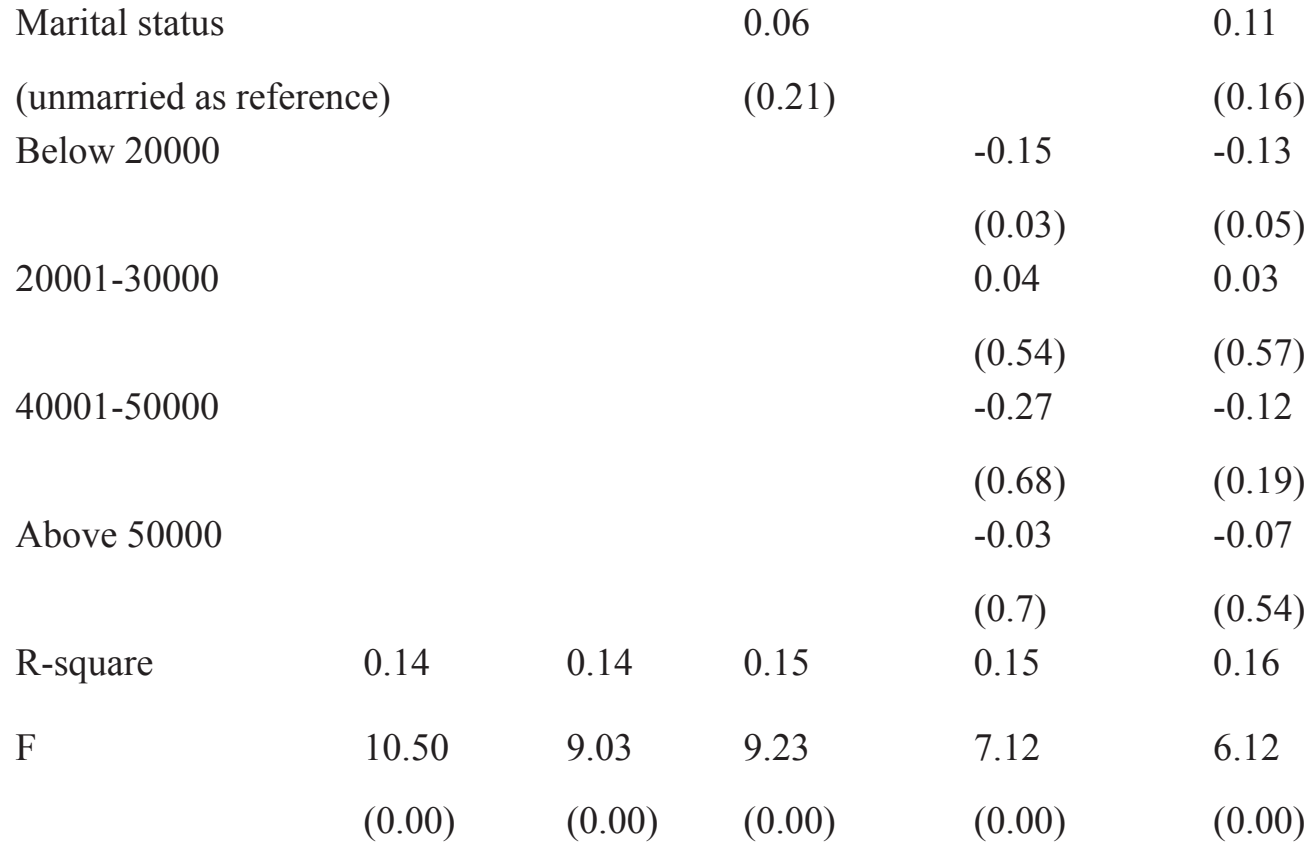

Notes: ${ }^{*}$ Figures in the parenthesis are p-values

${ }^{*}+2$ is taken as reference for variable parental educational background

* 30001-40000 taken as reference for variable income

The $\mathrm{p}$-value of $\mathrm{F}$ statistics is less than 5 percent in all the models presented in the table 5 which means all models postulates statistically significant. So it can be inferred that regression models are the good fit for the data.

The regression analysis shows positive significant relationship between peers and saving behavior of the Nepalese youth. The hypothesis 1 is supported. It means that there is significant influence of peers to saving behavior of the Nepalese youth.

The beta coefficient for parental financial teaching is statistically significant in all five different models with positive value. It indicates that parental financial teaching affect the saving behavior of the Nepalese youth positively. Hypothesis 3 is also supported.

Regarding parental educational background, it finds that the coefficient is statistically insignificant at 5 per cent level of significance. It indicates that the parental educational background cannot influence the saving behavior of the Nepalese youth. The result is contradict with Gratz (2006) who found that higher the education of the parents have they are more likely to teach their children and help them to take decisions. The study also found statistically insignificant influence of gender, marital status and income of 
Nepalese youth on their saving behavior. Thus, the hypothesis 2 and 4 are not supported. The results contradict with the findings of Falahati and Paim (2012). The study found significant impact of gender on saving behavior as male and female perceive different levels of financial knowledge, financial skills and consumer experiences. Regarding income impact on saving behavior, the results contradict with Delafrooz and Paim (2011), who found income influence the saving behavior. The marital status had insignificant impact on saving behavior which in line with the study of Grinstein-Weiss, Zhan and Sherraden (2006). However, they found married youth tend to save more than unmarried youth.

\section{Conclusion}

The study is conducted among the Nepalese youth who have completed Master's degree and employed of the Kathmandu Valley regarding the influence of parents and peer in the saving behavior. The impact of parental educational background, parental financial teaching and peers on the saving behavior is explored.

The most important motives for saving of the Nepalese youth were savings for emergencies, travelling and fulfilling the daily needs. The results show positive relationship between parental financial teaching and peer influence on saving behavior. Different financial teaching strategies like guidance and discussion, habit formation and independence and for peer influence socialization, comparison of financial status, spending time with peers and discussion of the financial matters are studied. For saving behavior willingness to save, propensity to save in future and total savings are measured.

In this study, parental financial teaching and peers are the influential factor of saving behavior of the Nepalese youth. Receiving financial teaching results in increment of willingness to save, total savings and ability to save. The Nepalese youth tend to maintain sound saving behavior if their parents encourage them to save as parents play facilitating and promoting role on the saving behavior. Involving in financial matters with peers increases the saving behavior of the Nepalese youth.

Based on this study it can be concluded that Nepalese youth consider involvement of parent and peer in financial decisions and behavior. Parents need to guide and support their children about personal financial management so that children can take sound decisions. Likewise people should also consider the effect of peers on them.

\section{References}

Bashir, T., Hassan, A., Nasir, S., Baber, A., \& Shahid, W. (2013). Gender differences in saving behavior and its determinants: Patron from Pakistan. Journal of Business and Management, 9(6), 74-86. 
Browning, M., \& Lusardi, A. (1996). Household saving: Micro theories and microfacts. Journal of Economic Literature, 34(4), 1797-1855.

Bucciol, A. \& Veronesi, M. (2014). Teaching children to save: What is the best strategy for lifetime savings? Journal of Economic Psychology, 45, 1-17.

Delafrooz, N., \& Paim, L. H. (2011). Effects of demographic characteristics, financial literacy and management on saving behavior of Malaysian employees. Asia Life Sciences, 21(1), 85-93.

Dhakal, S. (2012). International remittances, household expenditures and saving: Evidence from Nepal (Unpublished master's thesis), Norwegian University of life Sciences, Norway.

Dowling, N A, Corney, T \& Hoiles, L. (2009). Financial management practices and money attitudes as determinants of financial problems and dissatisfaction in young male Australian workers, Journal of Financial Counseling and Planning, 20(2), 5-13.

Falahati, L., \& Paim, L. (2012). Gender differences in saving behavior determinants among university Students, Journal of Basic and Applied Scientific Research, 2(6), 5848-5854.

Firmansyah, D. (2014). The influence of family backgrounds toward student's saving behavior: a survey of college students in Jabodetabek. International Journal of Scientific and Research Publications, 14(1), 1-6.

Friedline, L. T., Elliott, W., \& Nam, I. (2011). Predicting savings from adolescence to young adulthood: A propensity score approach. Journal of the Society for Social Work and Research, 2(1), 1-22.

Furnham, A. (1985). Why do people save? Attitudes to, and habits of, saving money in Britain. Journal of Applied Social Psychology, 15(5), 354-373.

Grable, J.E., Park, J., Joo, S., 2009. Explaining financial management behavior for Koreans living in the United States, Journal of Consumer Affairs, 43(1), 80-105.

Gratz, J. (2006). The impact of parents' background on their children's education, Educational Studies, 268, 1-12.

Grinstein-Weiss, M., Zhan, M., \& Sherraden, M. (2006). Saving performance in individual 
58 The International Research Journal of Management Sceince

Vol.3 No. 1 December 2018/ISSN 2542-2510

development accounts: Does marital status matter? Journal of Marriage and Family, 68, 192-204.

Horne, J. C. V., Wachowicz, J. M. (2008). Fundamentals of financial management. (13th ed.). Harlow: Prentice Hall.

Jamal, A. A., Mohidin, R., Osman, Z., Ramlan, K. W., \& Karim, A. M. (2015). The effects of social influence and financial literacy on savings behaviour: A study on students of higher learning institutions in Kota Kinabalu Sabah. International Journal of Business and Social Science, 6(11), 110-119

Karunaanithy, K., Karunanithy, M., \& Santhirasekaram, S. (2017). Understanding and responding to youth savings behaviour: Evidence from undergraduates in the war torn regions of Sri Lanka. International Journal of Research and Development, 2(1), 124-131.

Katona, G. (1975). Psychological economics. New York: Elsevier Scientific Publication Company.

Lusardi, A., Mitchell, S. L., \& Curto, V. (2010). Financial literacy among the young, Journal of Consumer Affairs, 44(2), 358-380.

Nepal, R. S., \& Thapa, S. B. (2015). Financial literacy in Nepal: A Survey analysis from college students, NRB Economic Review, 27(1), 50-74.

Nepal Rastra Bank. (2016). Study reports fifth household budget survey 2014-2015. Retrieved from https://www.nrb.org.np/red/publications/study_reports/Study_ Reports_Fifth_Household_Budget_Survey_2014-2015.pdf.

Otto, A.M.C. (2009). The economic psychology of adolescent saving (Doctoral dissertation). Retrieved from

https://eric.exeter.ac.uk/repository/handle/10036/83873

Otto, A. (2013). Saving in childhood and adolescence: Insights from developmental psychology. Economics of Education Review, 33, 8-18.

Otto, A. M., Schots, P. A., Westerman, J. A., \& Webley, P. (2006). Children's use of saving strategies: An experimental approach. Journal of Economic Psychology, 27(1), 5772 . 
Peng, T., Bartholomae, S., Fox, J., \& Cravener, G. (2007). The impact of personal finance education delivered in high school and college courses, Journal of Family and Economics, 28(2), 265-284.

Salikin, N., Wahab, N. A., Zakaria, N. Masruki, R., \& Nordin, S. N. (2012). Students saving attitude: Does parents background matter? International Journal of Trade, Economic, 3(6), 479-484.

Shim, S., Barber, B. L., Card, N. A., Xiao, J. J., \& Serido, J. (2009). Financial socialization of first year college students: The roles of parents, work, and education. Journal of Youth and Adolescence, 39(12), 1457-1470.

Warneryd, K.-E. (1999). The psychology of saving: A study on economic psychology. Cheltenham: Edward Elgar Publishing.

Webley, P. \& Nyhus, K. E. (2006). Parents' influence on children's future orientation and saving. Journal of Economic Psychology, 27(1), 140-164.

Webley, P., \& Nyhus, K. E. (2013). Economic socialization, saving and assets in European young adults. Economics of Education Review, 33, 19-30.

Xiao, J. J., \& Noring, F. E. (1994). Perceived saving motives and hierarchical financial needs. Journal of Financial Counseling and Planning, 5, 25-45.

Youniss, J., \& Haynie, L. D. (1992). Friendship in adolescene. Journal of Developmental \& Behavioral Pediatrics, 13(1), 59-66.

Appendix

Questionnaire

Section 1: Demographic Information

\section{Gender}

- Male

- $\quad$ Female

Age

- 21-25

- 26-30

- 31-35 


\section{Educational Degree}

- MBA

- $\quad \mathrm{MBS}$

\section{Marital Status}

- $\quad$ Married

Monthly Income

- Below 20000

- 20001-30000

- 30001-40000

- 40001-50000

- $\quad$ Above 50000

\section{Monthly Savings}

- Below 5000

- 5001-10000

- 10001-15000

- 15001-20000

- $\quad$ Above 20000

Educational Background of Parents

\begin{tabular}{lll}
\hline Level & Father & Mother \\
\hline None & $(0)$ & $(33)$ \\
Below SLC & $(90)$ & $(132)$ \\
SLC & $(112)$ & $(110)$ \\
+2 & $(83)$ & $(72)$ \\
Bachelors & $(65)$ & $(33)$ \\
Masters & $(40)$ & $(10)$ \\
\hline
\end{tabular}

\section{Section 2: Saving Behavior}

This questionnaire is to describe Saving Behavior. Please answer all items on this answer sheet. Please answer this questionnaire anonymously. The word "Peer" means your friends. 
1. What are the items being saved for? (Tick all that apply)

- Study

- Accommodation

- Clothes

- Vehicles

- Travel

- Other

2. If you do save, provide the reasons for saving? (Tick all that apply)

- $\quad$ Parents tell me to

(176)

- Peer save

- $\quad$ For daily needs

- $\quad$ For emergencies

- For a holiday

- Others

3. State your level of agreement and disagreement with the following statements about the purpose of saving by ticking the appropriate box.

\begin{tabular}{|l|l|l|l|l|l|l|}
\hline \multicolumn{2}{|l}{ I. Statements pertaining to Peer Influence } & $\begin{array}{l}\text { Strongly } \\
\text { disagree } \\
\text { S.N. }\end{array}$ & $\begin{array}{l}\text { Disagree } \\
\mathbf{( 2 )}\end{array}$ & $\begin{array}{l}\text { Not } \\
\text { sure } \\
\mathbf{( 3 )}\end{array}$ & $\begin{array}{l}\text { Agree } \\
\mathbf{( 4 )}\end{array}$ & $\begin{array}{l}\text { Strongly } \\
\text { Agree (5) }\end{array}$ \\
\hline 1 & $\begin{array}{l}\text { As far as I know, some } \\
\text { of my friends regularly } \\
\text { do save with a saving } \\
\text { account. }\end{array}$ & 14 & 56 & 107 & 153 & 60 \\
\hline 2 & $\begin{array}{l}\text { I always discuss about } \\
\text { money management issue } \\
\text { (saving) with my peers. }\end{array}$ & 21 & 63 & 134 & 112 & 60 \\
\hline 3. & $\begin{array}{l}\text { I always involve in } \\
\text { financial activities with } \\
\text { peers. }\end{array}$ & 12 & 54 & 100 & 155 & 69 \\
\hline 4. & $\begin{array}{l}\text { I always compare the } \\
\text { amount of saving and } \\
\text { spending with peers. }\end{array}$ & 15 & 52 & 111 & 143 & 69 \\
\hline
\end{tabular}


II. Statements pertaining to Saving Behavior

\begin{tabular}{|c|c|c|c|c|c|c|}
\hline S.N & Description & $\begin{array}{l}\text { Strongly } \\
\text { disagree } \\
\text { (1) }\end{array}$ & $\begin{array}{l}\text { Disagree } \\
\text { (2) }\end{array}$ & $\begin{array}{l}\text { Not sure } \\
\text { (3) }\end{array}$ & $\begin{array}{l}\text { Agree } \\
\text { (4) }\end{array}$ & $\begin{array}{l}\text { Strongly } \\
\text { Agree (5) }\end{array}$ \\
\hline 1. & $\begin{array}{l}\text { I don't manage to save } \\
\text { up for something that } \\
\text { would imply saving for } \\
\text { longer than } 1 \text { month. }\end{array}$ & 10 & 47 & 125 & 160 & 48 \\
\hline 2. & $\begin{array}{l}\text { I save because it is good } \\
\text { thing to do. }\end{array}$ & 2 & 49 & 251 & 62 & 26 \\
\hline 3. & $\begin{array}{l}\text { By saving you can } \\
\text { impress others }\end{array}$ & 15 & 48 & 96 & 147 & 84 \\
\hline 4 & $\begin{array}{l}\text { When I get money, } \\
\text { I always spend } \\
\text { immediately }\end{array}$ & 31 & 66 & 132 & 104 & 57 \\
\hline 5 & $\begin{array}{l}\text { Managing to save } \\
\text { makes me feel proud of } \\
\text { myself. }\end{array}$ & 22 & 49 & 95 & 143 & 81 \\
\hline 6 & $\begin{array}{l}\text { I don't save because I } \\
\text { think it is too hard. }\end{array}$ & 34 & 75 & 142 & 98 & 41 \\
\hline 7 & $\begin{array}{l}\text { I put money aside on } \\
\text { a regular basis for the } \\
\text { future. }\end{array}$ & 5 & 38 & 125 & 168 & 55 \\
\hline 8 & $\begin{array}{l}\text { I always follow careful } \\
\text { monthly budgeting. }\end{array}$ & 12 & 43 & 79 & 153 & 103 \\
\hline 9 & $\begin{array}{l}\text { I always have money } \\
\text { available in the event of } \\
\text { emergency. }\end{array}$ & 17 & 54 & 109 & 136 & 74 \\
\hline 10 & $\begin{array}{l}\text { In order to save, I } \\
\text { plan to reduce my } \\
\text { expenditure. }\end{array}$ & 17 & 58 & 97 & 155 & 63 \\
\hline 11 & $\begin{array}{l}\text { I save to achieve certain } \\
\text { goals. }\end{array}$ & 13 & 49 & 117 & 137 & 74 \\
\hline
\end{tabular}




\begin{tabular}{|c|l|c|c|c|c|c|}
\hline 12 & $\begin{array}{l}\text { I save because it gives } \\
\text { me feeling of security. }\end{array}$ & 0 & 31 & 100 & 185 & 74 \\
\hline 13 & $\begin{array}{l}\text { Household plans to put } \\
\text { money aside in next 12 } \\
\text { months. }\end{array}$ & 10 & 53 & 103 & 155 & 69 \\
\hline
\end{tabular}

\section{Statement pertaining to parental influence}

\begin{tabular}{|l|l|c|l|l|l|l|}
\hline S.N & Description & $\begin{array}{l}\text { Strongly } \\
\text { disagree } \\
\text { (1) }\end{array}$ & $\begin{array}{l}\text { Disagree } \\
\mathbf{( 2 )}\end{array}$ & $\begin{array}{l}\text { Not } \\
\text { sure (3) }\end{array}$ & $\begin{array}{l}\text { Agree } \\
\mathbf{( 4 )}\end{array}$ & $\begin{array}{l}\text { Strongly } \\
\text { Agree (5) }\end{array}$ \\
\hline 1 & $\begin{array}{l}\text { My parents encourage me } \\
\text { to save money. }\end{array}$ & 10 & 36 & 73 & 167 & 104 \\
\hline 2 & $\begin{array}{l}\text { My parents try to teach me } \\
\text { how to do budgeting. }\end{array}$ & 19 & 55 & 109 & 133 & 74 \\
\hline 3 & $\begin{array}{l}\text { I can spend the money as I } \\
\text { pleased. }\end{array}$ & 17 & 59 & 96 & 155 & 63 \\
\hline 4 & $\begin{array}{l}\text { I receive allowance from } \\
\text { my parents on regular } \\
\text { basis. }\end{array}$ & 12 & 49 & 118 & 136 & 75 \\
\hline
\end{tabular}

